\title{
Humanity's distance to nature: time for environmental austerity?
}

\author{
Ralf Seppelt $\mathbb{D} \cdot$ Graeme S. Cumming
}

Received: 25 April 2016/Accepted: 19 July 2016/Published online: 25 July 2016

(C) Springer Science+Business Media Dordrecht 2016

\section{Introduction}

We live at a point in the earth's history at which human impacts on the environment are, for the first time, threatening not only the local but also the global functioning of ecosystems (Running 2012). With nowhere else to go, humanity must answer an overwhelmingly important question: given the existing constraints of population growth and economic demand, how can we reduce our impacts on our life support system? Current debate on this topic appears to be polarizing around two extremes. On one side, the 'ecomodernists' have argued that people should distance themselves from nature to reduce their impacts on it (Anonymous 2015). On the other, environmentalists have argued that people protect what they know and love, and that by distancing

R. Seppelt $(\square)$

Department Computational Landscape Ecology, UFZ Helmholtz Centre for Environmental Research,

04318 Leipzig, Germany

e-mail: ralf.seppelt@ufz.de

R. Seppelt

Institute of Geoscience \& Geography, Martin-LutherUniversity Halle-Wittenberg, 06099 Halle (Saale),

Germany

G. S. Cumming

ARC Centre of Excellence in Coral Reef Studies, James

Cook University, Townsville, QLD 4811, Australia humanity from nature, we will lose our understanding and appreciation of it (Pergams and Zaradic 2008).

Both positions tend to elicit strong responses. The issue itself is, however, extremely complex. At the heart of the dilemma that our distance from nature raises are the same dynamics that currently prevent us from taking remedial action despite very clear scientific evidence that solving problems such as anthropogenic climate change requires immediate and extensive action, if indeed it is not already too late.

We briefly review the influences of technological development, globalization and urbanization and show that "distance to nature" is both problem and solution. Resolving this dilemma requires reducing our distance to nature through information about biodiversity and enhancing contact with nature, while increasing it by reducing our global footprint, avoiding lock-ins to unsustainable economics, and fostering innovations and experiments. Sustainability depends on adopting a form of environmental austerity to reduce the environmental debt that societies have already accumulated.

\section{How did we get here and what does it mean?}

The last two centuries have seen unprecedented technological and cultural development. This has provided the base for population growth and economic development while making old ways of livingparticularly, depending primarily on the land and locally produced goods and services-redundant 
(Morton 2007). Upscaling of food production from local to global has been made possible by advances (such as intensification, improved infrastructure, new technologies, and the growth of regional markets) that have led to profound changes in patterns of settlement and land use (Foley et al. 2011). It is relatively easy in most cities to obtain not only staple foods but also products that are produced far away and/or are locally out of season. Large segments of the human population have been freed from the constraints of local food production and have become refocused on the pursuit of non-ecosystem services, such as consumer goods and entertainment.

More than 300 years after the invention of the steam engine and 105 years after discovering how to produce mineral fertilizers, only a small proportion of the world's population directly experiences the dependence of their well-being on nature (Raudsepp-Hearne et al. 2010). Although still $46 \%$ of the world's population lives in the countryside, it is unclear how heavily these communities depend on local natural resources. In wealthy societies, living in the countryside is often a lifestyle choice for people who participate in other income-generating activities (Prince 2016); and in less developed nations, the rural poor may be heavily subsidized by remittances from family members who work in cities (Adams 1998; Christiaensen and Todo 2014). As cities have grown and the balance of economic wealth has shifted out of the countryside, rural communities have declined. In Sweden, for example, while other sectors have grown, fewer farmers now produce more food than they did a 100 years ago (Fig. 1). Rural areas and marginalized communities, the easily ignored and powerless of today's world, bear much of the impact of society's demands in the form of environmental degradation and biodiversity loss (Foale et al. 2013).

Humanity is now a dominantly coastal, urbandwelling species. Our withdrawal from natural environments, coupled to our ability to integrate over spatial variation by sourcing food and other goods from a wide variety of markets, has allowed many people to forget about the realities of ecosystem change and uncertainty. These trends-particularly technological development, globalization and urbanization-have had various important implications for society's relationship to nature. Such implications may be both positive and negative in terms of how they affect human impacts on the biosphere.
On the positive side the major trends of the Anthropocene provide some notable opportunities in relation to information, communication, and mass action. An increased and better flow of information has brought people closer together (the "global village"; Bunch and Hellemans 2004) and having accurate information on resource availability is key to finding a path to sustainable development, as proposed in the Sustainable Development Goals of the United Nations (UN General Assembly 2015). Our capacity for monitoring and measuring changes in earth systems is higher now than at any point in the past. The depth of information about the natural world that is available, ranging from simple educational material and documentaries to cutting-edge earth observation systems, also means that people can have a better appreciation of nature and threats to nature than ever before (Schulze et al. 2015).

Relatively recent development of the capacity to communicate globally, quickly and cheaply, means that news about environmental change and events can spread rapidly though the sections of the human population with access to these technologies. Knowledge about best management practices under given climatic and environmental conditions, and advance warnings of drought and disease, are already available; for example, via mobile phones for rural African farmers (CGIAR 2010). Communication can also be used to coordinate and motivate mass action in new ways. Events such as those unfolding during the Arab Spring of 2010 to 2012 would have been unthinkable in the absence of new communication technologies. Social media played an important role in communication between activists coordinating demonstrations and protests in the countries of the Arab League and its surroundings, leading to civil change (McGarty et al. 2014). Communication can also allow the voices of the disempowered, such as marginalized communities who have felt the effects of upscaled urban demand, to be heard.

The obvious negative implications of current trends in human-environment relationships relate to externalization, relevance, and demand.

Externalization or 'make it someone else's problem', is a consequence of globalization of the global resource use system. For example, the environmental and socioeconomic impacts of biofuels have been among the most hotly contested policy issues over the past decade, with US and European Energy policies causing indirect land use effects (Liu et al. 2015). Similarly, the volume of globally traded virtual water 
Fig. 1160 years of development of agriculture in Sweden (Edvinsson 2004). a Value added to Swedish economy by agriculture: proportional contribution drops heavily but total contribution increases. b Displays numbers of people employed in Sweden since 1840 by sector. This shows a heavy decline in number of people working in agriculture
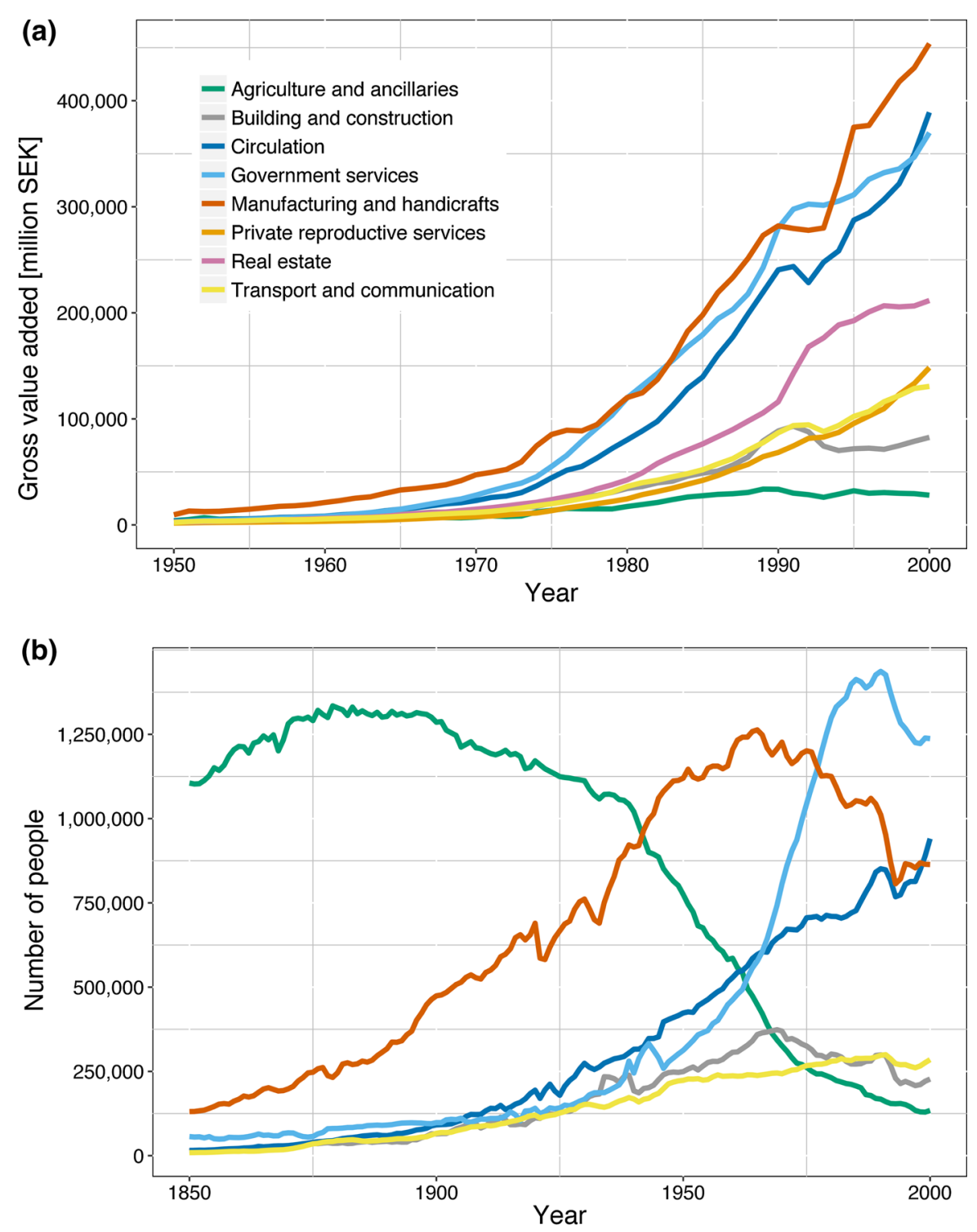

(i.e., water traded among countries as goods are traded) has doubled from 1986 to 2010 (Carr et al. 2013).

Relevance or 'we care less', derives from reduced contact and experience. As human interactions with nature change, so do our conceptions of what is normal in our local environment, what is important, and what level of change is acceptable. City dwellers-now the majority of the global population-may have a very forgiving concept of what constitutes a degraded landscape, and gradual environmental change can exacerbate acceptance of environmental change via shifting baseline syndrome, where knowledge is lost because younger generations are not aware of past conditions or as individuals forget their own past experiences (Papworth et al. 2009).

Demand or 'we want more', is a major problem in relation to increasingly wealthy urban populations. As wealth increases, people increase their consumption of luxury foods (e.g. fresh fruits, meat) and their demands for other natural resources or derived products (fibre, fuel), Fig. 2. If markets do not truly capture the environmental costs of upscaling, and if no one experiences limitations in resource availability, then there is no perceived limit on demand for resources or waste disposal. Increasing resource use efficiency may 


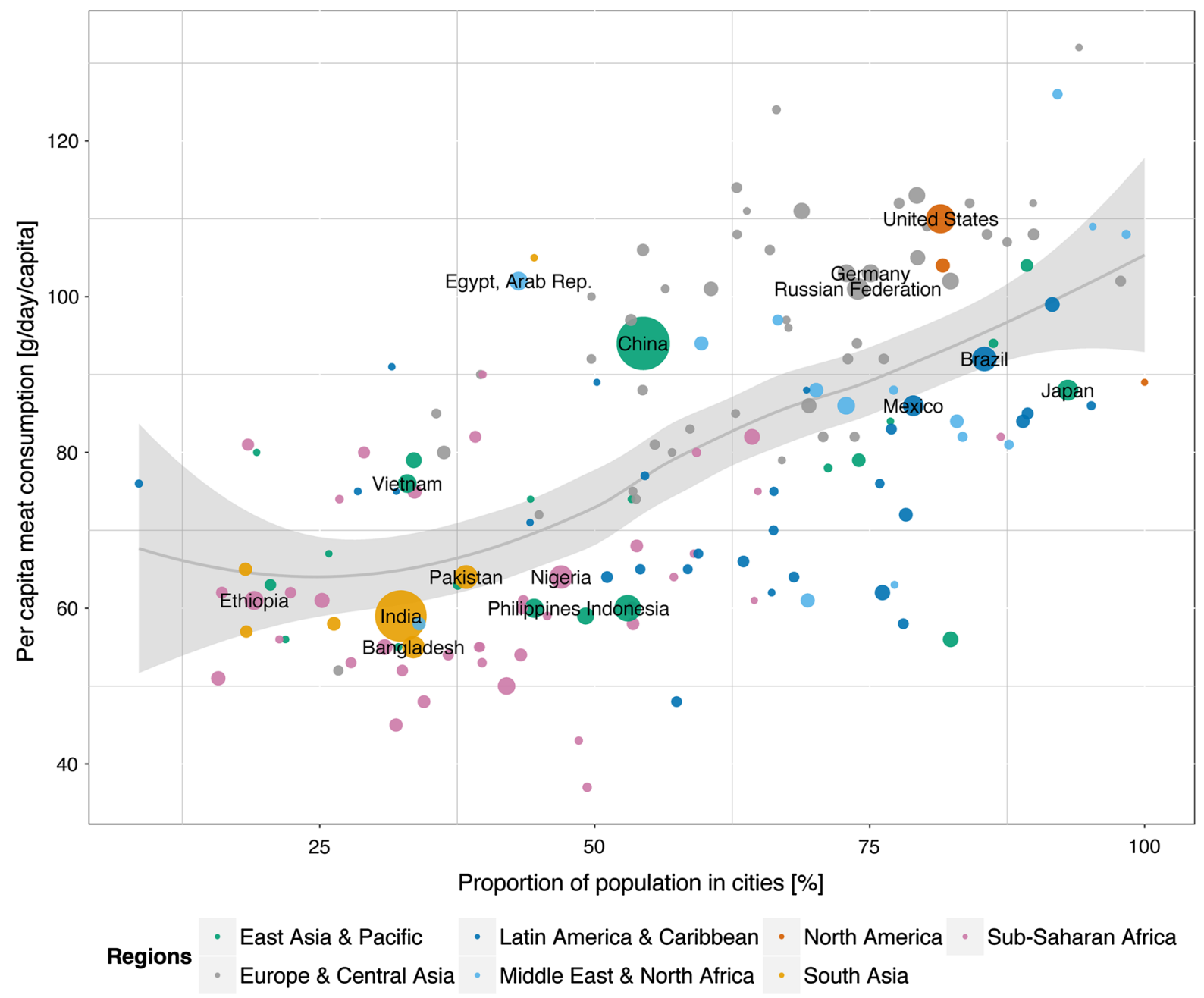

Fig. 2 Urbanization and meat consumption of 162 countries with available data from the FAO for year 2014 (FAO 2014). The more people life in urbanized areas the more likely is a

lead to greater consumption via rebound-effects (Alcott 2005). In the absence of local signals of ecosystem stress, human over-consumption becomes likely (Cumming et al. 2014).

\section{Solutions}

An increased distance between human societies and nature is part of modern human civilization in the Anthropocene. However, to argue that a greater distance to nature per se is the solution for future development is a core misconception that pervades recent environmental debates. Humans have altered nutrient rich diet, i.e. meat consumption per day per capita. Size of the points indicates total population, if above 80 Mio. country names are plotted

the earth's climate, its oceans, and the majority of its terrestrial surface (Ellis 2015). A land-sparing strategy of setting aside areas with pristine habitat 'for nature', and segregating people from nature, is neither sensible nor sufficient (Fischer et al. 2014; von Wehrden et al. 2014). It is based on the optimistic but questionable assumption that intensification and innovation can continue in the same way that they have done for the last decades to centuries. Production of renewable resources reached a peak between 1989 and 2008 (Seppelt et al. 2014), further photosynthetic efficiency is expected to be hard to achieve (Zhu et al. 2010), agriculture is encountering diminishing returns (Tilman et al. 2002), and future innovation requires 
expenditures on human capital (Huebner 2005; Fenichel and Zhao 2014).

Contact with nature and environmental change is central to both our desire and our capacity to care for the environment. Our distance to nature needs to be increased by reducing pressure on the environment, for example by closing the dietary gap, reducing waste, stopping deforestation, and reducing GHG emissions (Foley et al. 2011), rather than by taking people out of nature. To achieve a reduction in pressure, we therefore need a two-pronged strategy that includes both closeness and distance.

Closeness to nature can be fostered by bringing plants and animals back into cities, and by improving access to areas in which people can have contact with nature. Education, natural history observations, and communicating the improved understandings and interesting stories that science provides help to bring people closer to nature. Citizen science, for example, offers a fast-growing approach to getting people involved in exploring and understanding ecosystems (Silvertown 2009). Similarly, growing trends towards organic food, urban agriculture, and recognition of the value of local production, particularly through such venues as farmers' markets and schools, can help people to understand and learn about ecosystems, limits on ecological production, and sustainability (Falguera et al. 2012).

Distance to nature seems to be extremely difficult to achieve. Doing so will require that people are willing to regulate their own use of resources, or to let governments do so for them; essentially, we need a new form of environmental austerity. As a debated concept in fiscal policy (Connolly and Chrisafis 2012), the application of austerity in the field of human resource appropriation suggests that reducing our environmental debt on nature's capital (Barbier 2014) must be achieved either by

(1) Expenditure cuts (i.e., strictly preserving nature in protected areas and expanding natural areas even in locations that are not formally protected);

(2) Bringing our rate of usage and other impacts below the regeneration rate of ecosystems; and/ or

(3) Increasing tax, in the form of increased taxation (whether formal or de facto) of environmentally harmful economic activities.
Since industrialization, we have lived in an ecological deficit-spending world. Rebuilding natural capital takes time and space. Thus, by combining various measures of environmental austerity, it should in theory be possible to rein back over-exploitation and move human society towards a more responsible balance between consumption and conservation. Doing so in practice will, however, have implications for short-term economic growth. Implementing environmental austerity will require a clear mandate from society and binding commitments from governments and businesses.

Achieving a suitable balance between people and the rest of nature will also require innovation and experimentation, particularly in the areas of environmental governance and economics, where incentive structures designed to reduce consumption must be balanced against their political feasibility. Since economies cannot be decoupled from nature (Khan 2015), human societies will have to find pathways that maintain human wellbeing while moving out of consumption traps. Cities, with their local distancing effects, are not necessarily 'the' solution because of their effects on resource demands. While cities reduce some anthropogenic impacts, they magnify others, particularly if consumption patterns change in urban communities (e.g., increased demand for meat in urban environments). Recent theoretical advances suggest that these gradual changes (for instance, in resource limitation) should be interpreted as reasons to take immediate action to avoid crossing a threshold into collapse or degradation (Seppelt et al. 2014; Scheffer et al. 2015).

The temptations of simple solutions should be avoided in this debate, which has considerable complexity and many political and social implications. Differences in resource use between the developed world and the developing world, for example, raise difficult and important questions for reducing anthropogenic impacts on nature. If developed societies continue to demand increasing quantities of resources, then once local supply is exhausted or at full capacity, they will inevitably have to increase their scale of resource acquisition by exporting their demands to unexploited areas in less developed nations. As these nations develop in turn, they cannot follow the same approach because there will be nowhere left to exploit. The earth simply cannot provide a quality of life based on the consumption pattern of the richest societies for 
a population of 9 billion people. In the distance to nature debate, therefore, the plight of the poor cannot be ignored. Strategies for increasing our distance to nature without population declines can only be equitable if they are based on austerity and not simply on a handing-on of environmental problems and overexploitation from rich nations to poor. Technology, and particularly a shift away from fossil fuels to cheap sustainable energy, will remain a vital component of any solution. Good solutions to the sustainable use of landscapes need to be identified and quickly taken up by others (Wiens 2009). Since no single solution will work in every case, there is a need to improve social learning processes (Cundill et al. 2012). These processes must be strongly supported and fostered, for example by the creation of an insurance fund to provide security for communities that are willing to attempt broad-scale experimentation with more sustainable ways of living (Cumming et al. 2013).

With more people now alive than ever before, coupled with better nutrition and education, the number of innovative thinkers in the global population must now be higher than at any point in human history. The challenge for this mass of people will be to find ways of coping with and reducing the environmental debt societies already have accumulated—adopting a form of environmental austerity-while avoiding the simple, polarized views that currently characterize this complex debate.

\section{References}

Adams RH Jr (1998) Remittances, investment, and rural asset accumulation in Pakistan. Econ Dev Cult Change 47:155-173

Alcott B (2005) Jevons' paradox. Ecol Econ 54:9-21

Anonymous (2015) Decoupled ideals. Nature 520:407-408

Barbier EB (2014) Account for depreciation of natural capital. Nature 515:32-33

Bunch B, Hellemans A (2004) The history of science and technology. Houghton Mifflin Company, Boston

Carr JA, D’Odorico P, Laio F, Ridolfi L (2013) Recent history and geography of virtual water trade. PLoS One 8:e55825

CGIAR (2010) Mobile phones helping farmers making better decisions. http://www.cgiar.org/consortium-news/mobilephones-helping-farmers-make-better-decisions/. Accessed 8 Jan 2016

Christiaensen L, Todo Y (2014) Poverty reduction during the rural-urban transformation-the role of the missing middle. World Dev 63:43-58
Connolly K, Chrisafis A (2012) Anti-austerity movements gaining momentum across Europe. The Guardian. 27 April 2012. https://www.theguardian.com/world/2012/apr/27/ anti-austerity-movements-europe Retrieved 28 June 2016

Cumming GS, Olsson P, Chapin FS, Holling CS (2013) Resilience, experimentation, and scale mismatches in socialecological landscapes. Landscape Ecol 28:1139-1150

Cumming GS, Buerkert A, Hoffmann EM, Schlecht E, von Cramon-Taubadel S, Tscharntke T (2014) Implications of agricultural transitions and urbanization for ecosystem services. Nature 515:50-57

Cundill G, Cumming GS, Biggs D, Fabricius C (2012) Soft systems thinking and social learning for adaptive management. Conserv Biol 26:13-20

Edvinsson R (2004) Historical national accounts for Sweden 1800-2000. http://www.historicalstatistics.org. Accessed Jan 2016

Ellis EC (2015) Ecology in an anthropogenic biosphere. Ecol Monogr 85:287-331

Falguera V, Aliguer N, Falguera M (2012) An integrated approach to current trends in food consumption: moving toward functional and organic products? Food Control 26:274-281

FAO (2014) Food and Agriculture Organization of the United Nations FAOSTAT. http://faostat3.fao.org/faostat-gateway/ go/to/download/C/CC/E. Accessed Dec 2015

Fenichel EP, Zhao J (2014) Sustainability and substitutability. Bull Math Biol 77(2):348-367

Fischer J, Abson DJ, Butsic V, Chappell MJ, Ekroos J, Hanspach J, Kuemmerle T, Smith HG, von Wehrden H (2014) Land sparing versus land sharing: moving forward. Conserv Lett 7:149-157

Foale S, Adhuri D, Aliño P, Allison EH, Andrew N, Cohen P, Evans L, Fabiny M, Fidelman P, Gregory C, Stacey N, Tanzer J, Weeratunge N (2013) Food security and the Coral Triangle initiative. Marine Policy 38:174-183

Foley JA, Ramankutty N, Brauman KA, Cassidy ES, Gerber JS, Johnston M, Mueller ND, O'Connell C, Ray DK, West PC, Balzer C, Bennett EM, Carpenter SR, Hill J, Monfreda C, Polasky S, Rockström J, Sheehan J, Siebert S, Tilman D, Zaks DPM (2011) Solutions for a cultivated planet. Nature 478:337-342. doi:10.1038/nature 10452

Huebner J (2005) A possible declining trend for worldwide innovation. Technol Forecast Soc Chang 72:980-986

Khan MA (2015) Putting "Good Society" ahead of growth and/or "Development": overcoming neoliberalism's growth trap and its costly consequences. Sustain Dev 23:65-73

Liu J, Mooney H, Hull V, Davis SJ, Gaskell J, Hertel J, Lubchenco J, Seto KC, Gleick P, Kremen C, Li S (2015) Systems integration for global sustainability. Science 347:1258832-1258833

McGarty C, Thomas EF, Lala G, Smith LG, Bliuc AM (2014) New technologies, new identities, and the growth of mass opposition in the Arab Spring. Polit Psychol 35:725-740

Morton JF (2007) The impact of climate change on smallholder and subsistence agriculture. Proc Natl Acad Sci 104(50):19680-19685

Papworth SK, Rist J, Coad L, Milner-Gulland EJ (2009) Evidence for shifting baseline syndrome in conservation. Conserv Lett 2:93-100 
Pergams ORW, Zaradic PA (2008) Evidence for a fundamental and pervasive shift away from nature-based recreation. Proc Natl Acad Sci 105:2295-2300

Prince S (2016) Craft-art in the Danish countryside: reconciling a lifestyle, livelihood and artistic career through rural tourism. J Tour Cult Chang 1-20. doi:10.1080/14766825. 2016.1154064

Raudsepp-Hearne C, Peterson GD, Tengö M, Bennett EM, Holland T, Benessaiah K, MacDonald KG, Pfeifer L (2010) Untangling the environmentalist's paradox: why is human well-being increasing as ecosystem services degrade. BioScience 60:576-589

Running SW (2012) A measurable planetary boundary for the biosphere. Science 337(6101):1458-1459

Scheffer M, Barrett S, Carpenter SR, Folke C, Green AJ, Holmgren M, Hughes TP, Kosten S, van de Leemput IA, Nepstad DC, van Nes EH, Peeters ETHM, Walker B (2015) Creating a safe operating space for iconic ecosystems. Science 347:1317-1319

Schulze J, Martin R, Finger A, Henzen C, Lindner M, Pietzsch K, Werntze A, Zander U, Seppelt R (2015) Design, implementation and test of a serious online game for exploring complex relationships of sustainable land management and human well-being. Environ Model Softw 65:58-66

Seppelt R, Manceur AM, Liu J, Fenichel EP, Klotz S (2014) Synchronized peak-rate years of global resources use. Ecol Soc 19:50

Silvertown J (2009) A new dawn for citizen science. Trends Ecol Evol 24(9):467-471

Tilman D, Cassman KG, Matson PA, Naylor R, Polasky S (2002) Agricultural sustainability and intensive production practices. Nature 418:671-677

UN General Assembly (2015) Transforming our world: the 2030 Agenda for Sustainable Development. United Nations, New York

von Wehrden H, Abson DJ, Beckmann M, Cord AF, Klotz S, Seppelt R (2014) Realigning the land-sharing/land-sparing debate to match conservation needs: considering diversity scales and land-use history. Landscape Ecol 29:941-948

Wiens JA (2009) Landscape ecology as a foundation for sustainable conservation. Landscape Ecol 24:1053-1065

Zhu X-G, Long SP, Ort DR (2010) Improving photosynthetic efficiency for greater yield. Annu Rev Plant Biol 61:235-261 